\title{
CONSUMPTION OF THE WHOLE-GRAIN RYE BREAD AND PROGRESSION OF PROSTATE CANCER
}

\author{
Laila Meija*,**, Vinita Cauce*, Inese Siksna**, Rafaels Joffe***, Gita Ignace*,

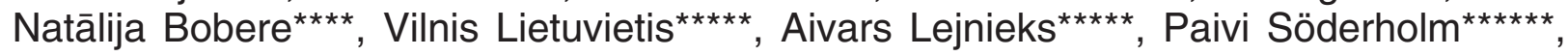 \\ and Herman Adlercreutz ${ }^{\star \star \star \star \star \star}$ \\ * Rīga Stradiṇš University, Dzirciema iela 16, Rīga, LV-1007, LATVIA; \\ laila@meija.Iv \\ ** Pauls Stradiṇš Clinical University Hospital, Pilsonu iela 13, Rīga, LV-1002, LATVIA \\ *** Institute of Food Safety, Animal Health and Environment „BIOR”, Lejupes iela 3, Rīga, LV-1076, LATVIA \\ ${ }^{* \star * *}$ Food Chemistry Centre, Department of Chemistry, University of Latvia, Kr. Valdemāra iela 48, Rīga, LV-1013, LATVIA \\ **** Rīga Eastern Clinical University Hospital, Hipokrata iela 2, Rīga, LV-1038, LATVIA

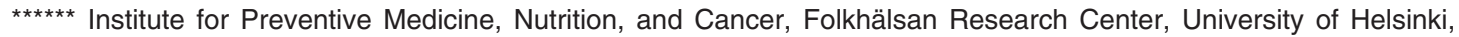 \\ P.O.B. 63, FIN-00014, Helsinki, FINLAND
}

Communicated by Valdis Pīrāgs

\begin{abstract}
Whole-grain rye intake has been suggested to have anti-cancer effect, including changes in serum hormones and reduced prostate specific antigen (PSA) in animals and humans. In this study, we investigated the effect of high intake of whole-grain rye bread on prostate cancer progression as assessed by PSA concentration in men diagnosed with prostate cancer. Fifteen men with prostate cancer who did not receive prior therapy were randomised and given a daily supplement of $250 \mathrm{~g}$ refined wheat bread for two weeks and, afterwards, $250 \mathrm{~g}$ whole-grain rye bread for six weeks. Blood samples were taken from fasting men at baseline and after two and six weeks to measure the PSA and sex hormones. The dietary intake was: energy intake 3452 kcal; protein intake $166 \mathrm{~g}$, carbohydrate intake $334 \mathrm{~g}$, fat $149 \mathrm{~g}$, saturated fat intake $52 \mathrm{~g}$, and fibre intake $40 \mathrm{~g}$. Plasma total PSA, free PSE, testosterone concentrations and free androgen index tended to be higher after refined white bread treatment and lower after whole-grain rye treatment. However, none of the differences were statistically significant. There were no significant changes in sex hormone binding globulin, luteinising hormone, and follicle stimulating hormone. In this intervention trial, whole-grain rye consumption did not result in significant changes in PSA and sex hormones, which may be related to high fat intake. Further prospective trials are indicated to evaluate the potential of whole-grain rye bread, taking into account other factors.
\end{abstract}

Key words: rye bread, prostate cancer, PSA, sex hormones.

Prostate cancer is the second most common cancer among men worldwide and the most common cancer in Latvia (Ferlay et al., 2008). Diet is suggested to play a role in both the incidence and progression of prostate cancer (Syed et al., 2007). One of possible protective diet factors is rye bread. Rye bran has been suggested to have anti-cancer effects. Rye bread is a rich source of bioactive compounds, including insoluble and soluble fibre, lignans, alkylresorcinols, vitamins, such as thiamine, riboflavin, vitamin $\mathrm{E}$, folate and minerals — iron, zinc, magnesium, and manganese (Adlercreutz, 2010). One of the most potent protective substances are lignans which are a class of phytoestrogens and predominant phytoestrogens in the diet in Western countries (Zamora-Ros et al., 2012). Lignans are diphenolic plant compounds, which are converted by the in- testinal microflora to bioactive compounds that can have both estrogenic and antiestrogenic effects (Adlercreutz, 2007). Lignans have been implicated in prostate cancer prevention and in delay of progression of prostate cancer, which is sex-hormone dependent. Possible protective mechanisms are effects on synthesis and metabolism of sex hormones, as well as on proliferation, apoptosis, angiogenesis and antioxidative activity (Adlercreutz, 2002). Lignans are found in very high concentrations in flaxseed, as well as in many other foods: vegetables, berries and fruits and in whole grain cereals, especially rye (Milder et al., 2005), which is the most important source of dietary fibre and lignans in Northern European countries like Sweden and Finland (Hedelin et al., 2006; Nurmi et al., 2010) and probably Latvia (Meija et al., 2012). There is some evidence to 
PARTICIPANT BASELINE CHARACTERISTICS

\begin{tabular}{lc}
\hline \multicolumn{1}{c}{ Characteristics } & Mean $\pm \mathrm{SD}$ \\
\hline Age $($ year $)$ & $66.3 \pm 4.6$ \\
Weight $(\mathrm{kg})$ & $80.6 \pm 12.6$ \\
Height $(\mathrm{m})$ & $173.3 \pm 8.5$ \\
Body mass index $\left(\mathrm{kg} / \mathrm{m}^{2}\right)$ & $26.7 \pm 3.1$ \\
PSA $(\mu \mathrm{g} / \mathrm{L})$ & $8.4 \pm 5.4$ \\
Free PSA $(\mu \mathrm{g} / \mathrm{L})$ & $1.1 \pm 0.7$ \\
Gleason grade & $4 \div 8$ \\
Testosterone $(\mathrm{ng} / \mathrm{ml})$ & $3.7 \pm 1.3$ \\
SHBG $(\mathrm{nmol} / \mathrm{L})$ & $45.9 \pm 21.9$ \\
LH $(\mathrm{IU} / \mathrm{L})$ & $4.8 \pm 1.5$ \\
FSH $(\mathrm{IU} / \mathrm{L})$ & $7.8 \pm 3.5$ \\
\hline
\end{tabular}

SHBG: sex hormone binding globuline; LH: luteinising hormone; FSH: follicle stimulating hormone

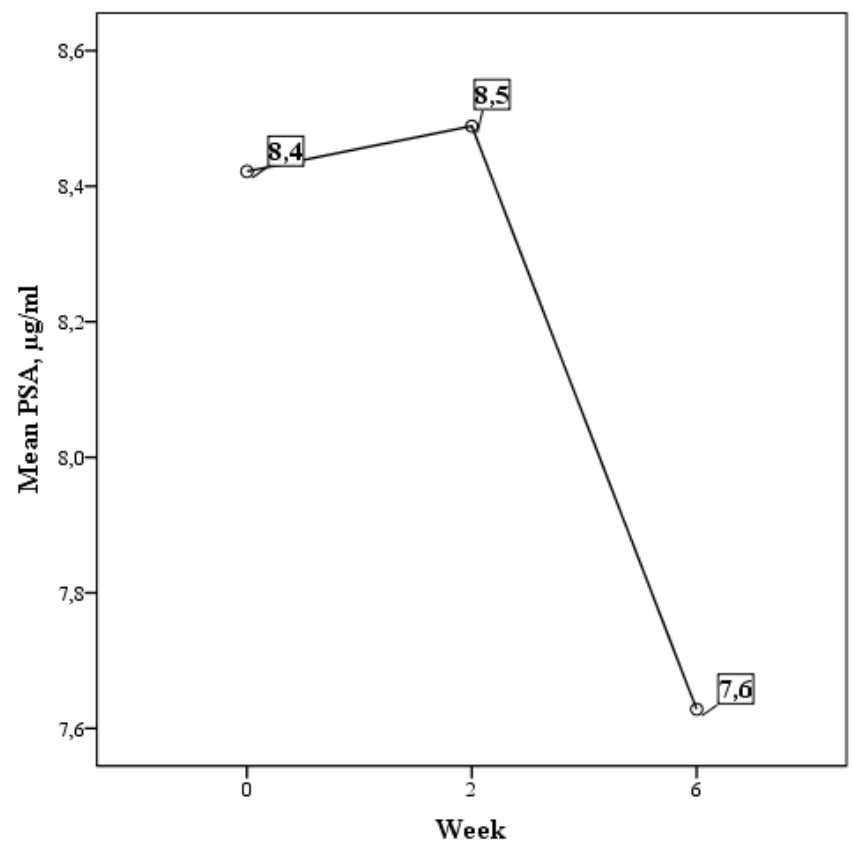

Fig. 1. PSA serum concentration during intervetion with bread $(0-$ baseline, 2-week treatment with refined wheat bread, 6-week treatment with whole grain rye bread).

suggest that rye bread may act against prostate cancer. Epidemiological studies on cereal fiber have shown inconclusive results (Anonymous, 2007; Park et al., 2011). Animal studies with prostate tumour implants have shown reduction of PSA concentration, tumour volumes and slower tumour growth after rye bran treatment (Landström et al., 1998; Bylund et al., 2000). A small human intervention study in men with prostate cancer showed that a diet rich in rye bread resulted in higher apoptosis in prostate tumours after three weeks (Bylund et al., 2003). Another intervention study in prostate cancer patients found that whole grain and bran from rye resulted in significantly lower plasma PSA (prostate specific antigen), compared with refined wheat bread, which could be explained by decreased exposure to insulin, as indicated by lower plasma insulin and urinary C-peptide (Landberg et al., 2010).

In this intervention study, we investigated the intermediate term effects of whole grain rye bread on prostate cancer progression assessed by concentration of tumour-associated biomarker PSA and free PSA in men with early stage prostate cancer. We also investigated serum concentrations of sex hormones as factors that may be involved in the mechanisms mediating growth-inhibitory effects on prostate cancer.

Participants and study design. Fifteen men with new diagnosis of prostate cancer were recruited for this study. The men were identified at the Outpatient Department of Riga Eastern Clinical University Hospital. The study was conducted on an out-patient basis. Patients were studied in the time period before surgical treatment. Inclusion criteria were histologically verified prostate cancer, local stage T2-T3, serum PSA: 1.9-22.7 $\mu \mathrm{g} / \mathrm{L}$, and age between 57 and 71 years. Exclusion criteria were vegetarian diet, gastrointestinal diseases, and lifestyle changes made by patients. All data were collected between November 2011 and May 2012. The study was approved by Research Ethics Committee of Pauls Stradinš Clinical University Hospital. All participants signed an informed consent. Each participant completed a general questionnaire concerning lifestyle factors, past and current morbidity.

Patients were prescribed a two-week washout period with wheat bread followed by six-week intervention period with rye bread. Treatment effects were evaluated after two and six weeks.

Diet and bread rations. Participants were instructed by the dietician to keep their habitual diet except for bread, which was replaced by intervention foods: refined wheat bread $250 \mathrm{~g}$ for two weeks and $250 \mathrm{~g}$ whole-grain rye bread for the next six weeks. The rye bread was designed specifically for the purpose of the present study. The wheat bread supplement consisted of 12 slices of soft bread $(250 \mathrm{~g})$ with content of $605 \mathrm{kcal}, 20.3 \mathrm{~g}$ protein, $4.3 \mathrm{~g}$ fat, $121.5 \mathrm{~g}$ carbohydrate and $5.4 \mathrm{~g}$ fibre. Whole-grain rye bread consisted of 5 slices of soft bread ( $250 \mathrm{~g}$ ) with an energy content $537.5 \mathrm{~g}$ $\mathrm{kcal}, 16 \mathrm{~g}$ protein, $1.3 \mathrm{~g}$ fat, $115.8 \mathrm{~g}$ carbohydrates and 23.3 $\mathrm{g}$ fibre. The participants were contacted by phone weekly by the dietician to ensure compliance. All men completed the study.

Usual food consumption, referring to the preceding year, was assessed by trained dieticians using a 147-item, country-specific food frequency questionnaire (FFQ). For portion size assessment, the FFQ was used together with a colour photographs folder with different portion sizes of 144 food items. Nutrient and energy intake were calculated using originally developed software, which contained the German Nutrient Data Base (Bundesinstitut für gesundheitlichen Verbraucherschütz und Veterinärmedizin, Berlin, Germany). 
Blood collection and laboratory assays. Fasting blood samples were collected in the morning at baseline and after two and six weeks of treatment. Blood drawn from antecubital vein was collected in EDTA-coated vacuum tubes. PSA were analysed by the Chemiluminescent Microparticle Immunoassay (CMIA), Architect,Abbott. Testosterone, sex hormone-binding globulin (SHBG), luteinising hormone (LH) and follicle stimulating hormone (FSH) were quantified in serum with solid-phase, two site Chemiluminescent Immunometric assay, Immulite 2000, Siemens.

Statistics. The baseline characteristics of the participants are presented as means \pm standard deviation. Repeated measurement analysis and paired t-test were used to compare PSA concentration between the treatment periods and baseline. Tests were two-sided and $P<0.05$ was considered significant. Statistical analyses were carried out with SPSS statistical software (version 20.0).

Baseline characteristics for men in the study group are presented in Table 1. Most patients were overweight. Overall, participants complied well with consuming the advised bread; only one participant did not fully reach the advised amount for bread and consumed $200 \mathrm{~g}$ rye bread. None of the participants reported any adverse effects during the experimental period.

Analysis of food frequency questionnaires showed that the mean energy intake was $3451.6 \mathrm{kcal}$, mean intake of fat $149.3 \pm 60.9 \mathrm{~g}$, saturated fat $51.6 \pm 23.5 \mathrm{~g}$, protein $166.4 \pm$ $65.5 \mathrm{~g}$, carbohydrate $333.7 \pm 147.7 \mathrm{~g}$, and fibre $40 \mathrm{~g}$. When expressed as a percent of total energy intake, mean intake of fat, saturated fat, protein and carbohydrates was $40.0 \%$, $13.5 \%, 20.3 \%$ and $39.7 \%$. The plasma total PSA, free PSA and testosterone tended to be higher after two-week treatment with refined wheat bread and lower after six-week treatment with whole grain rye bread. However, the differences were not statistically significant. Figure 1 shows PSA serum concentration changes after white wheat bread and rye bread consumption. There were no significant changes in sex hormone binding globuline, lutenising hormone and follicle stimulating hormone serum concentrations.

In this study, we found that PSA and free PSA concentrations tended to be higher after two weeks of wheat bread consumption and lower after six weeks of rye bread consumption. Although these changes are without statistical significance, this might indicate a possible rye bread effect on prostate cancer progression, considering that PSA is a possible biomarker for prostate cancer activity (Sandblom et $a l$., 2002). This finding is supported by results from animal models where rye bran treatment was shown to reduce plasma PSA concentration in mice with LNCaP tumour implants within three and six weeks (Bylund et al., 2000). Also, in one human study, six-week intervention with whole grain and bran from rye caused a $14 \%$ reduction in total PSA concentration compared with that after a refined wheat diet. However, another human study did not find changes in
PSA concentration after high intake of rye bran bread (Bylund et al., 2003). Possible mechanisms of PSA reduction may be related to fibre fermentation processes in the gut. Rye bread contains considerable amounts of soluble fibre, which are fermented to short chain fatty acids (SCFA), such as butyrate, propionate and acetate (Bach Knudsen et al., 2005). SCFA possesses anti-cancer activity (BeyerSehlmeyer et al., 2003) and also activates hepatic AMPactivated protein kinase, which lowers insulin secretion, and in this way influences prostate cancer progression (Lanberg et al., 2010). In addition, rye bread is a rich source of plant lignans, which have been suggested to prevent prostate cancer progression through different mechanisms, including affecting sex hormone metabolism. We found non-significant decrease of testosterone serum concentration, but no essential changes were seen in serum levels of SHBG, LH and FSH. The possible explanation why rye bread consumption did not result in significant changes in PSA and sex hormone concentrations is high fat intake. Dietary fat influences metabolism of plant lignans metabolites: enterolignans. High fat intake reduces enterolaclone formation in the gut and therefore reduces the protective effects of plant lignans, including on PSA and sex hormones (Adlercreutz, 2010).

The strength of our study was careful selection and monitoring of participants. We recognised some weaknesses of our study. The study group was small, and this had implications on the statistical power. Furthermore, only men with diagnosed prostate cancer were included, and whole-grain rye bread influence on PSA and sex hormone should be tested in control group men.

In conclusion, our study suggested that whole-grain rye bread might have beneficial effects on the progression of early prostate cancer. Further studies of longer duration and with a larger number of participants are needed to confirm these results.

\section{ACKNOWLEDGMENTS}

This study was supported by the project framework of the European Regional Development Fund (ERAF) No. 2010/0273/2DP/2.1.1.0/10/APIA/VIAA/083 „Assessment of Local Origin Cereal Species' Potential and Development of Varieties for Specific Dietary Foods Production”.

\section{REFERENCES}

Adlercreutz, H, (2002). Phyto-oestrogens and cancer. Lancet Oncol., 3 (6), 364-373.

Adlercreutz, H. (2007). Lignans and human health. Crit. Rev. Clin. Lab. Sci., 44 (5-6), 483-525.

Adlercreutz, H. (2010). Can rye intake decrease risk of human breast cancer? Food Nutr. Res., 54, doi: 10.3402/fnr.v54i0.5231.

Anonymous (2007). Food, Nutrition, Physical Activity, and the Prevention of Cancer: A Global Perspective. World Cancer Research Fund. Washington DC: AICR. 537 pp.

Bach Knudsen, K. E., Serena, A., Kjaer, A. K., Jørgensen, H., Engberg, R. (2005). Rye bread enhances the production and plasma concentration of 
butyrate but not the plasma concentrations of glucose and insulin in pigs. $J$. Nutr., 135 (7), 1696-1704.

Beyer-Sehlmeyer, G., Glei, M., Hartmann, E., Hughes, R., Persin, C., Böhm, V., Rowland, I., Schubert, R., Jahreis, G., Pool-Zobel, B. L. (2003). Butyrate is only one of several growth inhibitors produced during gut flora-mediated fermentation of dietary fibre sources. Brit. J. Nutr., 90 (6), 1057-1070.

Bylund, A., Zhang, J. X., Bergh, A., Damber, J. E., Widmark, A., Johansson, A., Adlercreutz, H., Aman, P., Shepherd, M. J., Hallmans, G. (2000). Rye bran and soy protein delay growth and increase apoptosis of human LNCaP prostate adenocarcinoma in nude mice. Prostate, 42 (4), 304-314.

Bylund, A., Lundin, E., Zhang, J. X., Nordin, A., Kaaks, R., Stenman, U. H., Aman, P., Adlercreutz, H., Nilsson, T. K., Hallmans, G., Bergh, A., Stattin P. (2003). Randomised controlled short-term intervention pilot study on rye bran bread in prostate cancer. Eur. J. Cancer. Prev., 12 (5), 407-415.

Ferlay, J., Shin, H. R., Bray, F., Forman, D., Mathers, C., Parkin, D. M. (eds.). GLOBOCAN 2008 v2.0, Cancer Incidence and Mortality Worldwide: IARC CancerBase No. 10. Lyon, France: International Agency for Research on Cancer; 2010. http://globocan.iarc.fr (last accessed on $15 \mathrm{Au}-$ gust 2012).

Hedelin, M., Klint, A., Chang, E. T., Bellocco, R., Johansson, J.-E., Andersson, S.-O., Heinonen, S.-M., Adlercreutz, H., Adami, H.-O., Grönberg, H., Bälter, K.A. (2006). Dietary phytoestrogen, serum enterolactone and risk of prostate cancer: The cancer prostate Sweden study (Sweden). Cancer Causes Control (CCC), 17 (2), 169-180.

Landberg, R., Andersson, S. O., Zhang, J. X., Johansson, J. E., Stenman, U. H., Adlercreutz, H., Kamal-Eldin, A., Aman, P., Hallmans, G. (2010). Rye whole grain and bran intake compared with refined wheat decreases urinary C-peptide, plasma insulin, and prostate specific antigen in men with prostate cancer. J. Nutr., 140 (12), 2180-2186.

Landström, M., Zhang, J. X., Hallmans, G., Aman, P., Bergh, A., Damber, J. E., Mazur, W., Wähäla, K., Adlercreutz, H. (1998). Inhibitory effects of soy and rye diets on the development of Dunning R3327 prostate adenocarcinoma in rats. Prostate, 36 (3),151-161.
Meija, L., Erdmane, D., Ignace, G., Siksna, I., Joffe, R., Lietuvietis, V., Lejnieks, A. (2012). Dietary fiber intake and food sources in aged men and women in Latvia. 5th International Dietary Fibre Conference 2012. Book of Abstracts, p. 65. Rome.

Milder, I. E. J., Arts, I. C. W., Van De Putte, B., Venema, D. P., Hollman, P. C. H. (2005). Lignan contents of Dutch plant foods: A database including lariciresinol, pinoresinol, secoisolariciresinol and matairesinol. Brit. J. Nutr., 93 (3), 393-402.

Nurmi, T., Mursu, J., Peñalvo, J. L., Poulsen, H. E., Voutilainen, S. (2010). Dietary intake and urinary excretion of lignans in Finnish men. Brit. J. Nutr., 103 (5), 677-685.

Park, Y., Subar, A. F., Hollenbeck, A., Schatzkin, A. (2011). Dietary fiber intake and mortality in the NIH-AARP diet and health study. Arch Intern Med., 171 (12), 1061-1068.

Sandblom, G., Holmberg, L., Damber, J. E., Hugosson, J., Johansson, J. E., Lundgren, R., Mattsson, E., Nilsson, J., Varenhorst, E. (2002). Prostate-specific antigen as surrogate for characterizing prostate cancer subgroups. Scand J. Urol Nephrol., 36 (2), 106-112.

Syed, D. N., Khan, N., Afaq, F., Mukhtar, H. (2007). Chemoprevention of prostate cancer through dietary agents: Progress and promise. Cancer Epidemiol. Biomarkers Prev., 16 (11), 2193-2203.

Zamora-Ros, R., Knaze, V., Lujan-Barrosso, L., Kuhnle, G., Mulligan, A., Touillaud, M., Slimani, N., Romieu, I., Powell, N., Tumino, R., Peeters, P. H. M., De Magistris, S., Ricceri, F., Sonested, E., Drake, I., Hjartaker, A., Skie, G., Mouw, T., Wark, P. A., Domaguera, D., Bueno-de-Mesquigta, H. B, Ros, M., Molina, E., Sieri, S., Quiros, J. R., Huerta, J. M., Tjonneland, A., Halkjaer, J., Masala, G., Teucher, B., Kaaks, R., Travis, R. C., Dilis, V., Benetou, V., Trichopoulou, A., Amiano, P., Ardanaz, E., Boeing, H., Forster, H., Clavel-Chapelon, F., Fagherazzi, G., Perquier, F., Johansson, G., Johansson, I., Cassidy, A., Overvad, K., Gonzales, C. A. (2012). Dietary intakes and food sources of phytoestrogens in the European Prospective Investigation into Cancer and Nutrition (EPIC) 24-hour dietary recall cohort. Eur. J. Clin. Nutr., 66 (8), 932-941.

Received 26 October 2012

\section{PILNGRAUDU RUDZU MAIZE UN PRIEKŠDZIEDZERA VĒŽA PROGRESIJA}

Pētījumi rāda, ka rudzu maizei iespējami pretvēža efekti, iedarbojoties uz dzimumhormoniem un mazinot prostatas specifisko antigēnu (PSA). Mēs pētījām rudzu maizes ietekmi uz priekšdziedzera vēža progresiju, izvērtējot izmainas PSA koncentrācijā. Piecpadsmit vīrieši ar diagnosticētu priekšdziedzera vēzi, kas nebija saņēmuši citu terapiju, divas nedēlas lietoja $250 \mathrm{~g}$ rafinēto miltu baltmaizi, pēc tam sešas nedēlas $250 \mathrm{~g}$ pilngraudu rudzu maizi. Tika noteikts PSA un dzimumhormoni pētījuma sākumā, pēc divām un sešām nedēlāām. Vidējie dati: uzṇemtās enerǵijas daudzums - $3451 \mathrm{kcal}$; uznemto uzturvielu daudzums dienā — 166 olbaltumvielu, $334 \mathrm{~g}$ ogḷhidrātu. $149 \mathrm{~g}$ tauku, $52 \mathrm{~g}$ piesātināto tauku, $40 \mathrm{~g}$ šķiedrvielu. PSA un testosterona koncentrācija plazmā atrasta augstāka pēc baltmaizes lietošanas un zemāka pēc rudzu maizes lietošanas, bet izmainas nebija statistiski nozīmīgas. Sekshormona saistošā globulīna, lutinizējošā hormona un folikulu stimulējošā hormona koncentrācija būtiski nemainījās. Šajā intervences pētījumā rudzu maizes lietošana būtiski nemazināja PSA koncentrāciju, ko, iespējams, var skaidrot ar lielo tauku daudzumu uzturā. Lai izvērtētu rudzu maizes potenciālos pretvēža efektus, nepieciešami turpmāki prospektīvi pētījumi, ṇemot vērā citus uztura un hormonālos faktorus. 